ECONOMICS

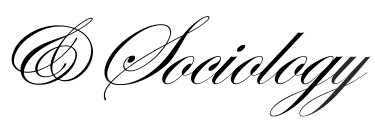

Oliinyk, V., Kozmenko, O., Wiebe, I., \& Kozmenko, S. (2018). Optimal Control over the Process of Innovative Product Diffusion: The Case of Sony Corporation. Economics and Sociology, 11(3), 265-285. doi:10.14254/2071789X.2018/11-3/16

\title{
OPTIMAL CONTROL OVER THE PROCESS OF INNOVATIVE PRODUCT DIFFUSION: THE CASE OF SONY CORPORATION
}

\author{
Viktor Oliinyk, \\ Sumy State University, \\ Sumy, Ukraine, \\ E-mail: oliynyk.vik.tor@gmail.com \\ Olga Kozmenko, \\ Kharkiv National University of \\ Economics, \\ Kharkiv, Ukraine, \\ E-mail: \\ kozmenko.uabs@gmail.com
}

Iryna Wiebe,

Sony Europe Limited, ZND

Deutschland,

Stuttgart, Germany,

E-mail:iryna.wiebe@outlook.de

Serhiy Kozmenko,

University of Customs and Finance,

Dnipro, Ukraine,

E-mail:serbiy@businessperspectives.org

Received: February, 2018

1st Revision: May, 2018

Accepted: August, 2018

DOI: $10.14254 / 2071-$

789X.2018/11-3/16

JEL Classification: C53, E37, O31, O33, Q55.

\begin{abstract}
The article deals with the process of distribution of an innovative product using the Bass model. Numerical characteristics of the generalized Bass model are described. The function of external influence is suggested to be approximated by means of a regression equation with respect to the price function of the product under investigation, which is also a control function. The control process is based on a mathematical apparatus under the Pontryagin maximum principle. An algorithm for determining the optimal price of products in order to obtain the maximum balance profit of the corporation is given. Selected numerical results of the corporate strategy implementation for conquering the market in 2017-2020 are offered.
\end{abstract}

Keywords: innovation models, innovation management, forecasting, Bass model.

\section{Introduction}

What are innovations and how do they differ according to their degree of novelty? Novelty is a very important feature of innovation, but it is viewed differently by numerous researchers (Reichardt, 2008). 
According to Robertson, the degree of novelty is related to the degree of behavioral change. He distinguishes three types of innovation: continuous, dynamically continuous and discontinuous innovation (Robertson, 1967).

An innovation process can differ in its beginning. For example, the science-pull and market-pull models differ only in their first step. In the science-pull model, the innovation process begins with basic research. Market demand is the first step in market-pull model. Those two models have the identical following steps: applied research, experimental development and finally innovation (Irvine \& Martin, 1984).

Gerpott distinguishes three types of innovation processes: the narrower, the extended and the broadest. The innovation process in the narrow sense only includes the product and / or process introduction activities. In a broader sense, research and development activities as well as the invention are added to introduction activities. The innovation process in the broadest sense includes the three steps mentioned above and will be supplemented by the market expansion at the end (Gerpott, 2005; Akhmetova, 2017; Ivanová \& Čepel, 2018).

Rogers $(1961,1969,2003)$ defines diffusion as a spread of an innovation over time, in which communication between members of one social system proceeds through certain communication channels. Rogers' innovation diffusion refers to both the planned and the spontaneous ideas spread. The novelty of these ideas is assumed.

Rogers' diffusion theory describes the spread of innovation in a social system. According to Rogers, the concept of innovation diffusion includes four basic elements: innovation, communication channels, time and the social system. Individuals play a major role in the diffusion process of innovation, as innovation spreads through the diffusion networks established by individuals. This innovation can be already known, but it has not yet been accepted or rejected by the person (Rogers, 2003).

An innovation has four characteristics: a relative advantage over the previous product or process, compatibility of innovation with existing values and needs of consumers, complexity of this innovation for one or another user, verifiability and observability of results. These characteristics influence the diffusion process and partially explain the different adoption rates (Rogers, 2003). Time is an important factor for innovation diffusion. The time dimension is used, for example, in the decision about an innovation or for the measurement of the diffusion rate. Without taking into account the time dimension researches cannot provide accurate results. The various communication channels also play different roles in the decision-making process. Therefore, communication channels which bring the greatest benefit should be used depending on the process step.

The aim of the study is to obtain a model for the dissemination of an innovative product, which is based on the Bass model (Bass, 1969) and the Generalized Bass model (GBM) (Bass et al., 1994). With the use of mathematical methods it is proposed to control the function of external influence and to obtain the optimal price for the sale of goods at the maximum balance profit. A forecast is made for future sales of an innovative product.

\section{Literature review}

Golder and Tellis (1998) offer a model for the distribution of durable goods, based on the concept of accessibility, rather than diffusion. The main limitations of the Bass model (1969) (the marketing variables are not taken into account, the parameters found are not stable, the forecasts are not accurate enough) in the proposed model were eliminated, especially when predicting and sustaining the parameters (Kozlovskyi, et al., 2018). The authors propose a model based on the Cobb-Douglas function. Golder and Tellis (2004) investigated 30 product categories for the analysis of the life cycle of durable goods. The main findings of their research is that new products for 8 years have a tendency to rapid 
growth ( $45 \%$ per year); the slowdown occurs at a time when sales of goods are down by $15 \%$ and remain below the previous sales peak for 5 years; sales decline occurs when about $50 \%$ of the total market potential is achieved and about $34 \%$ of population penetration.

The theoretical assumptions of the Bass diffusion model relative to the fact that this model describes the behavior of a homogeneous population are considered in Tanny and Derzko (1988). In their work they offer a two-compartment model regarding innovators and imitators and the distribution of the product is explained by the joint diffusion of these components.

Forecasting of the first adoptions of a new product is proposed by Easingwood et al. (1983). Authors offer a model of nonuniform influence (NUI), which involves the extension of the Bass model. The adequacy of the model is analyzed when five consumer durable goods are distributed.

Oren and Schwartz (1988) in their work suggest using the criterion of the maximum expected utility of a new product when it is chosen by the consumer. Depending on the dynamics of the market and the consumer's attitude toward risk, the logistic growth of the number of consumers of new products is shown.

Chatterjee and Eliashberg (1990) develop a model based on micromodelling. They consider consumers not prone to risk and the parameters of the model are determined through a survey of respondents. The product is accepted by the consumer, if the values of its parameters (price, risk) do not exceed their thresholds. Comparison of this model with diffusion models is given.

Horsky, D. (1990) considers the model for the distribution of a new product depending on its price and consumer income, and also takes into account the dynamics of sales growth based on word-of-mouth effects.

In his work, Olefirenko, O. (2016) deals with scientific and methodic approach to optimize distribution expenses of the innovatively active industrial enterprises in Ukraine. Economic and mathematic modeling methods allowed to formalize models to plan distribution expenses of innovatively active enterprise, demand and profits, that is prerequisite to form prognostications by proper directions.

Yurynets, Z., Yurynets R., and Gutor T. (2017) solved the task to assess the optimal output of innovative products by the company in order to maximize profits from the sale of developed products. The proposed model allows to determine the percentage of effective production of innovative products at the enterprise, considering the infrastructure of the market and competitive behavior in terms of overall range of products, the possibility of optimal correction of this ratio to increase profits from the sale of innovative products.

Steffens and Murthy (1992) offer a simple mathematical model describing the process of diffusion of consumer durables based on five parameters. In their model, the authors fix the fraction of innovators and imitators from the total number of users and, based on some assumptions, obtain an analytical solution to the task.

Redmond (1994) considers the Bass model at the spatial level, i.e. distribution of new products (color TV and VCRs) within the country is taken into account. Regional indicators of the Bass model are obtained, which depend on purchasing power, mobility and age of consumers.

For the process of distribution of the new product Bemmaor (1994), Bemmaor and Lee (2002) suggest a model based on the shifted Gompertz distribution (G/SG model). A cumulative distribution function that depends on two parameters is constructed. As a particular case, the exponential model and the Bass model are considered. The adequacy of the model was estimated by finding the predicted sales of twelve new products.

Song and Chintagunta (2003) offer an empirical model for predicting the spread of a new product. Accounting for the price, the number of sales and the presence of the brand 
allows to obtain various forms of the proposed model. They proved that for different brands, the price of a product at a certain point in time affects future sales.

Garber et al. (2004) in their work use the method of spatial divergence to predict the process of diffusion of a new product. In this model, it is assumed that the entire market is a matrix, the filling of which depends on both external and internal factors.

Deleersnyder et al. (2004) propose to consider the diffusion of durable goods together with fluctuations in business cycles. By analyzing time series, the authors came to the conclusion that the purchasing power of consumers directly depends on the cyclical fluctuations of business cycles. This conclusion was made based on the dynamics of sales of 24 durable products.

Urban et al. (1996) developed a virtual purchasing environment for modeling the sales of new products. The proposed approach allows the company to plan the implementation of its product depending on the current market change. The method "information acceleration" allows to predict the reaction of consumers to the appearance of new products on the market.

Ajzen (1991) deals with issues related to the theory of planned behavior (TPB) and shows that the obtained results on the basis of this theory are well supported by empirical data. Based on this theory, the consumer's behavior and his intention to buy this product depends on the attitude, subjective norms and behavioral control.

Ha (1998) suggests using theory of reasoned action (TRA) to analyze the consumer's loyalty attitude to the brand. Based on the research, eight variants of the relationship of customer loyal to the brand were developed, which are based on three variables. It is shown that the greatest effect of brand loyalty will be achieved when favorable conditions for the following indicators are created: attitude towards the behavior, purchase behavior and subjective.

To explain the internal motivations of users in using systems Lowry et al. (2013) offer the hedonic-motivation system adoption model (HMSAM). This model uses streaming cognitive absorption as a tool for analyzing the ease of use of the system and the behavioral intentions of users and has a practical application in the study of both hedonic-motivation systems (HMS) and utilitarian-motivation systems (UMS).

Lee et al., (2011) in their study combined two models: innovation diffusion theory (IDT) and TAM. An extended model is proposed to analyze the factors that influence the intention of business employees to use a computer-based e-learning system.

Bagozzi (2007) critically analyzes the shortcomings of the TAM system and in each specific case proposes correcting these shortcomings. The main component of the proposed model is the core of decision making, which reflects the desire of users to use this system.

Benbasat and Barki (2007) consider the application of the model for the study of information systems related to information technology (IT) and offer five recommendations for improving the model for making an IT decision. The authors study the application of utility theory to explain the relationship between IT characteristics and the users' perception of the proposed technology, as well as to introduce multistage models for finding meaningful persuasion variables.

To study consumer behavior in e-commerce, Chen et al. (2002) proposed to share TAM and IDT. The resulting model was analyzed using factor analysis for reliability and validity, and the causal relationship was investigated using structural equations.

Taylor and Todd (1995) compared the TAM model with two versions of the TPB model for adoption of information technology. It is shown that all models adequately assessed behavioral intentions, but TPB, based on the proposed factors, more fully reflected the behavior of users of the center of computer resources.

Venkatesh et al., (2003) conducted in-depth analysis of models associated with the use of new information technologies. The analysis allowed to approve a unified model of UTAUT 
(unified theory of acceptance and use of technology), which has four determinants of intent performance expectancy, effort expectancy, social influence, facilitating conditions and up to four moderators of key relationships. Qualitative indicators of this model reflect its adequacy and show superiority in relation to the individual models considered.

Kiwanuka (2015) analyzes the degree of IDT presence in the UTAUT model when adopting a new technology. In addition to the existing parameters, the author proposes to include in the model UTAUT additional variables from the theory of diffusion of innovations, reflecting the adoption phase of technology.

Kotsemir and Meissner (2013) and Marinova and Phillimore (2003) reviewed the research on innovative models and considered the advantages and disadvantages of the proposed models. The transition from a continuous model of the distribution of an innovative product to a discrete Bass (1969) proposes to be implemented using a regression model. Cumulative sales are used as independent variables. Boswijk and Franses (2005) and Srinivasan and Mason (1986) proposed alternative models of diffusion of the innovative product. Franses (2009) in his work considers the distribution of durable product. It shows that cumulative sales have the form of S-shape. Chandrasekaran and Tellis (2007), Sultan et al. (1990), Talukdar et al. (2002), Van Den Bulte, C. and Stremersch, S. (2004) in their studies obtained numerical characteristics of the Bass model parameters for some innovative products. Fruchter and Van den Bulte (2011) suggest including in GBM a variable reflecting the current position in the market. Guseo et al. (2007) proposed to model the external function by means of exponential discontinuities. Boehner and Gold (2012) suggested introducing a variable that reflects a mixed market effect.

Davis (1989), in his study of the adoption of a computer system (model TAM) on the basis of a regression model, suggested that the utility indicator of a system depends on the ease of using it. The causal relationship between these variables can be analyzed using the Granger causality test (Granger, 1969).

Cieślik and Michałek (2017), based on a model of Melitz (2003), proved that the probability of exporting is positively related to both product and process innovations (using the probit model applied to the fifth edition of the BEEPS firm level dataset covering 20112014). Somilarly Wach (2016) proved that implementing product or process innovation contributes to the intensification of the internationalization process of firms operating in hightech industries on the sample of 263 firms from Poland.

One of the main issues in the sale of goods on the market is finding potential users of this product. Pandey and Srivastava (2016) analyzed 100 scientific articles in the period 20092016 and classified antecedents that affect the purchase of goods in two categories: factors of consensus and factors of nonconsensus.

\section{Methodological approach}

This study is based on the Bass model, the external influence function is suggested to be approximated by using the time parameters and the sales price. This model allows to manage the price to obtain the desired result: obtaining the maximum balance profit at the forecasting period. The Pontryagin maximum principle is used as a mathematical apparatus. Numerical results of the optimal distribution process of the innovative product (Sony Corporation's, LCD TVs) are obtained depending on the number of potential users.

The main idea put in this study is based on the GBM model. The initial data were sales of Sony Corporation's (LCD TVs) product innovation for 2003-2016 with an interval of one year. When the parameters of the Bass model were found, the regression analysis apparatus was used. To predict the volume of sales and find the optimal price of the product, a method based on the Pontryagin maximum principle was used. As an optimization criterion, the 
indicator of balance profit was considered. Various models of innovative product distribution based on these principles are considered.

\section{Conducting research and results}

\subsection{Bass model}

The Bass (1969) theory starts with a population of $m$ potential adopters. For each of these adopters, the time to adoption is a random variable with a distribution function $F(t)$ and density $f(t)$, such that the hazard rate satisfies:

$$
\frac{f(t)}{1-F(t)}=p+q F(t)
$$

where $t$ refers to continuous time. The parameters $p$ and $q$ are associated with innovation and imitation, respectively.

The cumulative number of adopters at time $t$, denoted as $N(t)$. The function $N(t)$ satisfies the differential equation

$$
n(t)=\frac{d N(t)}{d t}=\left(p+\frac{q}{m} N(t)\right)[m-N(t)]
$$

For the transition from a continuous product distribution model to a discrete, Bass (1969) proposes to consider the regression model:

$$
X_{t}=N_{t}-N_{t-1}=p\left(m-N_{t-1}\right)+\frac{q}{m} N_{t-1}\left(m-N_{t-1}\right)+\varepsilon_{t}=a+b N_{t-1}+c N_{t-1}^{2}+\varepsilon_{t}
$$

where $a=p m ; b=q-p ; c=-q / m$; it is assumed that $\varepsilon_{t}$ is an independent and identically distributed error term with mean zero and common variance $\sigma^{2}$.

Derives the values $p, q, m$ from the estimated $a, b, c$ as follows:

$$
p=\frac{a}{m} ; q=-c m ; m=\left[-b \pm\left(b^{2}-4 a c\right)^{1 / 2}\right] /(2 c)
$$

The obtained values (4) can be used for further investigation of the distribution of the innovative product. The differential relation (2) with the parameters found $p, q, m$ makes it possible to obtain the regression equation for the actual initial data of the investigated product.

In what follows we will use (GBM) (Bass et al., 1994):

$$
n(t)=\frac{d N(t)}{d t}=\left(p+\frac{q}{m} N(t)\right)[m-N(t)] x(t)
$$

where $x(t)$ - the function of external market factors (time, price, advertising, region, competition, etc.).

Statement of the problem: it is necessary to find the optimal price of an innovative product in order to obtain the maximum gross profit (GP) in the period under study:

$$
G P(t)=n(t) \operatorname{Pr}(t) \rightarrow \max
$$

where $\operatorname{Pr}(t)$ - unit price of the product. 
INTERDISCIPLINARY APPROACH TO ECONOMICS AND SOCIOLOGY

\subsection{Pontryagin maximum principle}

\subsubsection{Statement of the problem of optimal control}

To find the characteristics of sales, we will use a method based on the Pontryagin maximum principle (Pontryagin et al., 1962). As a control function, we will consider price function $\operatorname{Pr}(t)$. We will consider GBM.

As a result, we obtain the following relations:

The equation of state of the system:

$$
\frac{d N(t)}{d t}=\left(p+\frac{q}{m} N(t)\right)[m-N(t)] x(t)
$$

Initial conditions:

$$
N\left(t_{0}\right)=N_{0}
$$

Management function has following form:

$$
x(t)=a \operatorname{Pr}(t)+b \operatorname{Pr}(t)^{2}+f(t),\left(\operatorname{Pr}(t) \geq \operatorname{Pr}_{\min }(t)\right)
$$

The optimization function is given in the form:

$$
\int_{t_{0}}^{T} n(t) \operatorname{Pr}(t) d t+\lambda N(T) \rightarrow \max
$$

\subsubsection{Solution of optimal control problem}

The solution of the problem is reduced to the following relations.

The system of equations:

$$
\left\{\begin{array}{l}
\frac{d N(t)}{d t}=\left(p+\frac{q}{m} N(t)\right)[m-N(t)]\left[a \operatorname{Pr}^{*}(t)+b\left[\operatorname{Pr}^{*}(t)\right]^{2}+f(t)\right] \\
\frac{d \Psi(t)}{d t}=-\left\{\left[\Psi(t)+\operatorname{Pr}^{*}(t)\right]\left[-p+q-\frac{2 q}{m} N(t)\right]\left[a \operatorname{Pr}^{*}(t)+b\left[\operatorname{Pr}^{*}(t)\right]^{2}+f(t)\right]\right\}
\end{array}\right.
$$

The initial conditions and transversality conditions have the form:

$$
N\left(t_{0}\right)=N_{0} ; \Psi(T)=-\lambda
$$

The optimal control function:

$$
\operatorname{Pr}_{1,2}^{*}(t)=-(a+b \Psi) \pm\left\{(a+b \Psi)^{2}-3 b[a \Psi+f(t)]\right\}^{1 / 2} /(3 b)
$$

From two possible solutions we choose one that satisfies the condition of the problem. If $b=0$, then

$$
\operatorname{Pr}^{*}(t)=-\frac{a \Psi(t)+f(t)}{2 a}
$$

Thus, the optimal distribution of the price function, taking into account the limitations, has the form:

$$
\operatorname{Pr}_{o p t}(t)= \begin{cases}\operatorname{Pr}_{1,2}^{*}(t), & t_{0} \leq t<t_{1} \\ \operatorname{Pr}_{\min }(t), & t_{1} \leq t \leq T\end{cases}
$$

The switching point $t_{1}$ is found from condition $\operatorname{Pr}_{1,2}^{*}(t) \leq \operatorname{Pr}_{\min }(t)$.

\subsection{The algorithm for finding the optimal solution}

The algorithm for finding the quantity of sales of an innovative product and the optimal price is presented in the form of the following stages. 
INTERDISCIPLINARY APPROACH TO ECONOMICS AND SOCIOLOGY

\begin{tabular}{|}
$\begin{array}{c}\text { Determination of the historical period of product } \\
\text { distribution. } \\
\text { Finding the coefficients of the regression equation (3) } \\
\text { and the parameters of the relation (2). } \\
\text { From the relation (5), taking into account the historical } \\
\text { period data, we find the function of external influence. }\end{array}$ \\
$\begin{array}{c}\text { Define the structure of the function: for example. } \\
\text { Based on historical data, we construct a regression } \\
\text { equation for the function. } \\
\text { We carry out the formulation of the problem of optimal } \\
\text { control. Method: the Pontryagin maximum principle. }\end{array}$ \\
We solve the problem of optimal control. \\
We analyze the results obtained.
\end{tabular}

Consider some optimization models for the distribution of Sony Corporation's innovative product: Sales of LCD TVs.

\subsection{Statement of the problem}

It is necessary to find the optimal price of the product (LCD TVs), which allows obtaining the maximum balance profit (6) during 2017-2020.

Table 1 presents the sales characteristics of LCD TVs during 2003-2016.

Table 1. Characteristics of sales of LCD TVs

\begin{tabular}{cccccccc}
\hline № & Year & $\begin{array}{c}\text { Sales, mln } \\
\text { units }\end{array}$ & $\begin{array}{c}\text { Operating } \\
\text { revenue,mln } \\
\text { yen }\end{array}$ & $\begin{array}{c}\text { Dollar rate } \\
\text { yen } \\
\text { (USD=YEN) }\end{array}$ & $\begin{array}{c}\text { Unit price, } \\
\text { yen, Pr(yen) }\end{array}$ & $\begin{array}{c}\text { Unit } \\
\text { price, \$, } \\
\operatorname{Pr}(\$)\end{array}$ & $\begin{array}{c}\text { Unit } \\
\text { price, } \\
\text { Pr, } \\
\text { (base } \\
2012)\end{array}$ \\
\hline 1 & 2003 & 0.43 & 925501 & - & - & - & - \\
\hline 2 & 2004 & 1 & 921195 & - & - & - & - \\
\hline 3 & 2005 & 2.8 & 927769 & - & - & - & - \\
\hline 4 & 2006 & 6.3 & 1226971 & - & - & - & - \\
\hline 5 & 2007 & 10.6 & 1367078 & - & - & - & - \\
\hline 6 & 2008 & 15.2 & 1275692 & - & - & - & - \\
\hline 7 & 2009 & 15.6 & 1005244 & - & - & - & - \\
\hline 8 & 2010 & 22.4 & 1199234 & - & - & - & - \\
\hline 9 & 2011 & 19.6 & 843464 & - & - & - & - \\
\hline 10 & 2012 & 13.5 & 581475 & 83.1 & 43072.22 & 518.31 & 1 \\
\hline 11 & 2013 & 13.5 & 754308 & 100.2 & 55874.66 & 557.63 & 1.075 \\
\hline 12 & 2014 & 14.6 & 835068 & 109.9 & 57196.43 & 520.44 & 1.004 \\
\hline 13 & 2015 & 12.2 & 797764 & 120.1 & 65390.49 & 544.46 & 1.050 \\
\hline 14 & 2016 & 12.1 & 720557 & 108.4 & 59550.16 & 549.35 & 1.059 \\
\hline
\end{tabular}

Source: Investor Relations, Sony, https://www.sony.net/SonyInfo/IR/financial/\#block1 
It is necessary to obtain the characteristics of the Bass model, which allow obtaining the most optimal distribution of the innovative product in the historical interval 2003-2016.

\subsection{Option A}

We find the parameters of the regression equation (3) on the basis of the data in Table 1.

The regression equation for future sales looks like this:

$$
X_{t}=4.83331^{* *}+0.35750^{* * *} N_{t-1}-0.00225^{* * *} N_{t-1}^{2}
$$

The characteristics of the regression equation

$R^{2}=0.723 ; R_{a j s}^{2}=0.668 ; p=0.0016^{* * *}$

Note:*.**.*** - Significant at $10 \% .5 \% .1 \%$ critical level

Using relations (4), we find the parameters of the Bass model:

$$
p=0.028143 ; q=0.385648 ; m=171.74 \text { mln units }
$$

The Graph 1 shows the distribution of historical data for the period 2003-2016 and the values obtained from the regression model (Bass model).

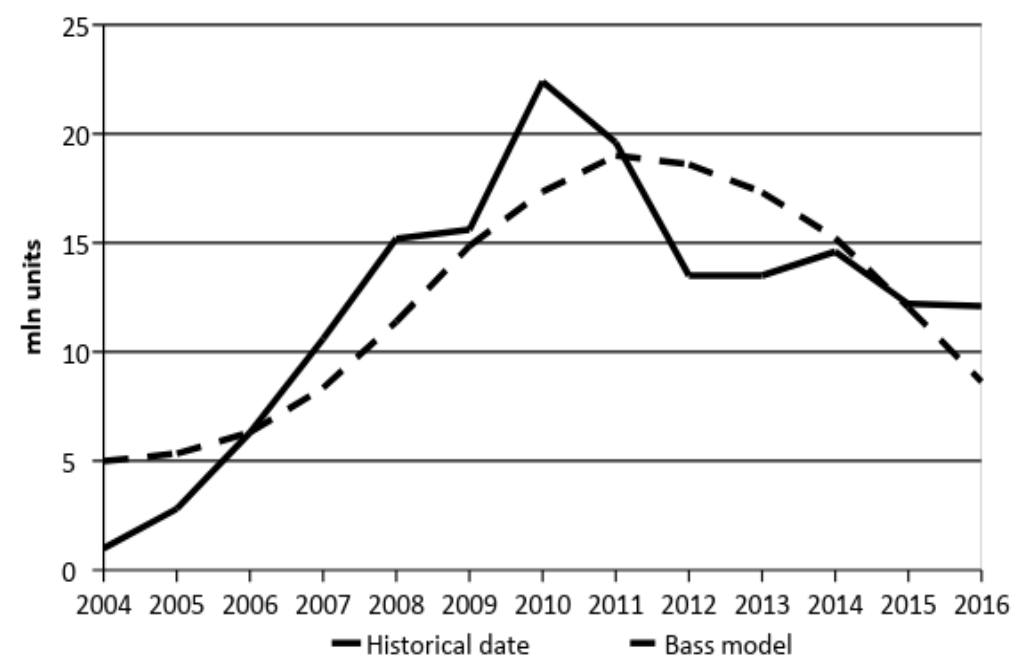

Graph 1. Sony Corporation: unit sales LCD TVs

Source: Investor Relations, Sony, https://www.sony.net/SonyInfo/IR/financial/\#block1

The Graph 2 represents the distribution of the external influence function on the historical period, found from the relation (7).

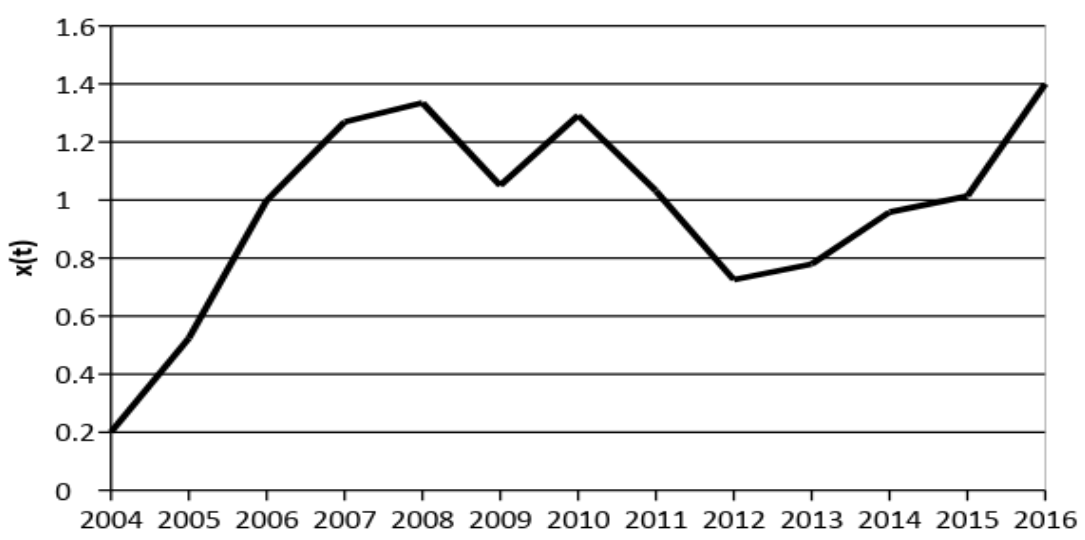

Graph 2. Distribution external function $x(t)$

Source: own data 
Thus, to find the forecast values of product sales, it is necessary to obtain a functional relationship between the external function $x(t)$ and the known parameters that affect the distribution of the product (time, price, advertising, etc.).

Let us consider several variants of regression equations approximating an external function. Gross profit (GP) is found from the relation $G P_{t+1}=n_{t+1} \operatorname{Pr}_{t}$.

\subsubsection{Option A1}

Based on the studies, we will construct a regression equation on the price parameter $\operatorname{Pr}$ ( $t$ (base 2012) in the interval 2012 $(t=1)-2016(t=5)$.

$$
\begin{aligned}
& y_{t}=1.181+0.164^{*} t-0.674 \mathrm{Pr}_{t} \\
& R^{2}=0.891 ; R_{a d j}^{2}=0.783 ; p=0.108 .
\end{aligned}
$$

Note: ***.***_- Significant at 10\%. 5\%. $1 \%$ critical level

The Graph 3 shows the approximation of the time series $x(t)$ by the regression equation (16).

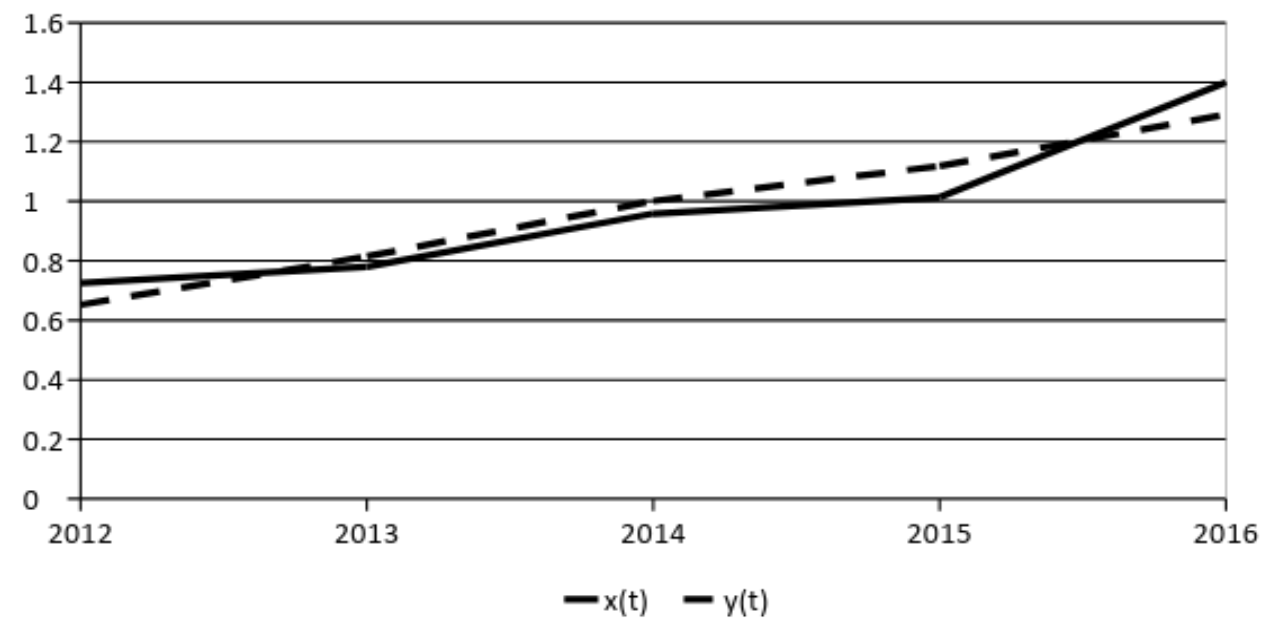

Graph 3. Distribution of external function

Source: own data

Thus, the external action function is described by the regression equation (16) and is a function of the price of the product $\operatorname{Pr}(t)$ (base 2012). In general, this function can be specified using more complex relationships and additional variables (time, advertising costs, etc.). The choice of the approximating function is one of the most important tasks in forecasting product promotion.

We will find the optimal price of the product $\left(\operatorname{Pr}_{\text {opt }}\right)$, which allows obtaining the maximum balance profit in the interval 2012-2020. The formulation of the problem is reflected in relations (7) - (10). The initial and final state of the system is set by the conditions: $N(2012)=107.43 \mathrm{mln}$ units and $N(2020)=170.58 \mathrm{mln}$ units. The minimum selling price is set at the level $\operatorname{Pr}_{\min }=0.5 \operatorname{Pr}(2012)$. The solution of the problem of optimal control of the price function is given in relations (11) - (13). Table 2 shows the corporation's strategy for the period 2012-2020 to conquer the LCD TVs sales market based on historical data and the calculated optimal values. In this case, the price of LCD TV in 2017-2020 can be set arbitrarily, taking into account the commodity market. 
INTERDISCIPLINARY APPROACH TO ECONOMICS AND SOCIOLOGY

Table 2. Sales of LCD TV (Option A1)

\begin{tabular}{|c|c|c|c|c|c|c|c|}
\hline \multirow[t]{2}{*}{$t$} & \multirow[t]{2}{*}{ Year } & \multicolumn{3}{|c|}{ Calculation based on historical data } & \multicolumn{3}{|c|}{ Optimization results } \\
\hline & & $\begin{array}{l}\text { Total sales, } \\
\text { mln units }\end{array}$ & $\begin{array}{c}\text { Unit price, } \\
\text { Pr, (base } \\
\text { 2012) }\end{array}$ & $\begin{array}{l}\text { Grossprofit } \\
\text { (GP), mln \$ }\end{array}$ & $\begin{array}{l}\text { Total sales, } \\
\text { mln units }\end{array}$ & $\begin{array}{l}\text { Unit } \\
\text { price, } \\
\mathrm{Pr}_{\text {opt }} \text {, } \\
\text { (base } \\
\text { 2012) }\end{array}$ & $\begin{array}{c}\text { Grossprofit } \\
\left(\mathrm{GP}_{o p t}\right) \\
\operatorname{mln} \$\end{array}$ \\
\hline 1 & 2012 & 107.43 & 1.000 & - & 107.43 & 1.15 & - \\
\hline 2 & 2013 & 119.40 & 1.075 & 6204.17 & 117.20 & 1.20 & 6081.73 \\
\hline 3 & 2014 & 132.06 & 1.004 & 7053.94 & 127.72 & 1.21 & 7006.62 \\
\hline 4 & 2015 & 144.06 & 1.050 & 6244.60 & 138.46 & 1.14 & 7431.48 \\
\hline 5 & 2016 & 153.90 & 1.059 & 5355.18 & 148.78 & 1.21 & 7087.37 \\
\hline 6 & 2017 & 161.25 & 1.000 & 4034.34 & 157.97 & 1.10 & 5744.50 \\
\hline 7 & 2018 & 166.19 & 0.900 & 2560.45 & 165.05 & 0.62 & 3155.89 \\
\hline 8 & 2019 & 169.09 & 0.850 & 1352.79 & 168.84 & 0.50 & 982.20 \\
\hline 9 & 2020 & 170.58 & 0.800 & 656.44 & 170.58 & 0.50 & 450.93 \\
\hline \multicolumn{2}{|c|}{ Amount } & - & - & 33461.91 & - & - & 37940.71 \\
\hline
\end{tabular}

Source: Investor Relations, Sony, https://www.Sony.net/SonyInfo/IR/financial/\#block1

\subsubsection{Option A2}

Suppose that sales of LCD TVs, in addition to the price of TVs, also depend on the activities of the corporation, namely: Cost of Sales (CS).

Table 3 presents the data of the corporation's activities on these indicators.

Table 3. Performance indicators of the corporation

\begin{tabular}{ccccc}
\hline \multirow{2}{*}{ № } & Year & \multicolumn{3}{c}{ Cost of sales } \\
\cline { 3 - 5 } & & Mln yen & CS $(\$), \operatorname{mln} \$$ & CS,(base 2012) \\
\hline 1 & 2012 & 4485425 & 53976.23 & 1 \\
\hline 2 & 2013 & 5140053 & 51297.93 & 0.9503 \\
\hline 3 & 2014 & 5275144 & 47999.49 & 0.8892 \\
\hline 4 & 2015 & 5166894 & 43021.59 & 0.7970 \\
\hline 5 & 2016 & 4753010 & 43846.95 & 0.8123 \\
\hline
\end{tabular}

Source: Investor Relations, Sony, https://www.sony.net/SonyInfo/IR/financial/\#block1

Let's find the regression equation on the interval 2012-2016.

$$
\begin{array}{r}
y_{t}=-2.032+0.340 t-0.903 \operatorname{Pr}_{t}+3.285 C S_{t} \\
R^{2}=0.985 ; R_{a d j}^{2}=0.940 ; p=0.155 .
\end{array}
$$

Note: *.**.***-Significant at 10\%. 5\%. 1\% critical level

The Graph 4 shows the approximation of the time series $x(t)$ by the regression equation (17). 


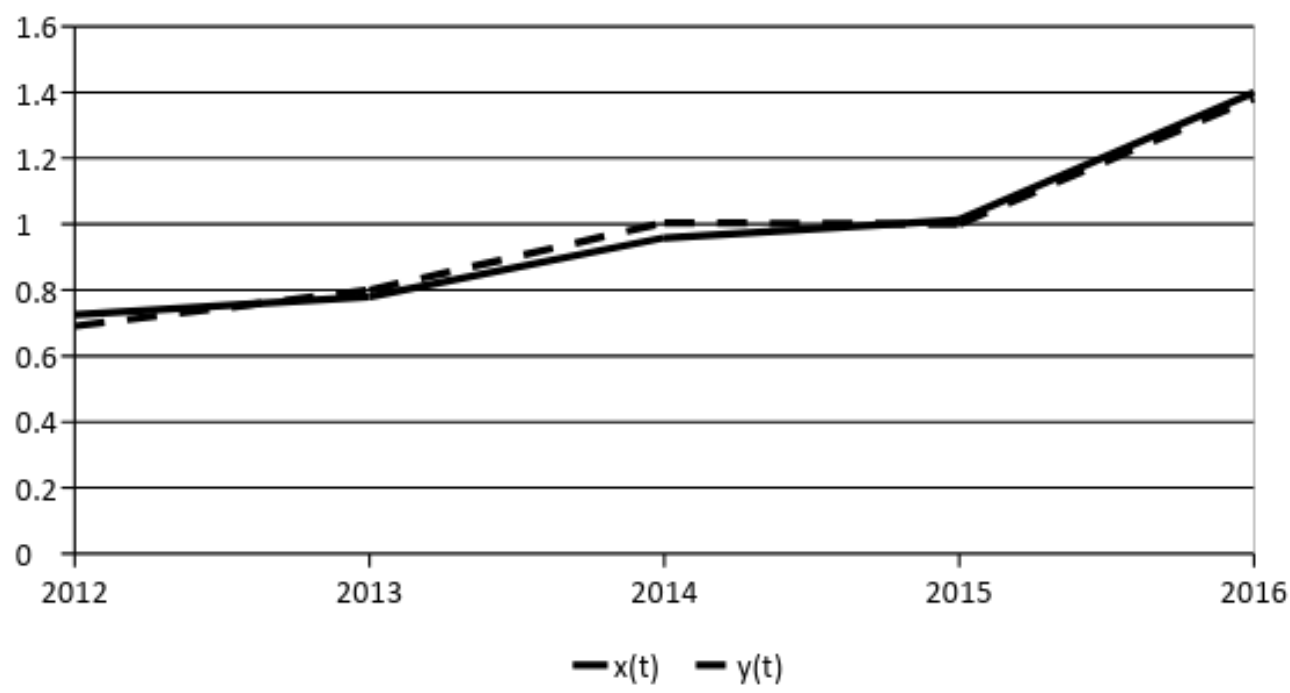

Graph 4. Distribution of external function Source: own data

We will find the optimal price of the product (Propt), which allows obtaining the maximum balance profit in the interval 2012-2020.The value of the indicator of cost of sales in the period 2017-2020 is assumed constant at $2016(\mathrm{CS}(2016)=43846.95 \mathrm{mln} \$)$. The solution of the problem of optimal control of the price function is given in formulae (11) (13)). The Table 4 presents the characteristics of LCD TV sales.

Table 4. Sales of LCD TVs (Option A2)

\begin{tabular}{|c|c|c|c|c|c|c|c|}
\hline \multirow[t]{2}{*}{$t$} & \multirow[t]{2}{*}{ Year } & \multicolumn{3}{|c|}{ Calculation based on historical data } & \multicolumn{3}{|c|}{ Optimization results } \\
\hline & & $\begin{array}{l}\text { Total sales, } \\
\text { mln units }\end{array}$ & $\begin{array}{l}\text { Unit price, } \\
\text { Pr, (base } \\
\text { 2012) }\end{array}$ & $\begin{array}{l}\text { Grossprofit } \\
\text { (GP), mln \$ }\end{array}$ & $\begin{array}{l}\text { Total sales, } \\
\text { mln units }\end{array}$ & $\begin{array}{l}\text { Unit price, } \\
\operatorname{Pr}_{\text {opt }} \\
\text { (base 2012) }\end{array}$ & $\begin{array}{c}\text { Grossprofit } \\
\left(\mathrm{GP}_{\text {opt }}\right) \\
\mathrm{mln} \$\end{array}$ \\
\hline 1 & 2012 & 107.43 & 1.000 & - & 107.43 & 1.150 & - \\
\hline 2 & 2013 & 118.82 & 1.075 & 5905.11 & 116.84 & 1.202 & 5606.51 \\
\hline 3 & 2014 & 130.53 & 1.004 & 6523.50 & 126.72 & 1.213 & 6155.95 \\
\hline 4 & 2015 & 140.95 & 1.050 & 5422.39 & 136.26 & 1.144 & 5998.52 \\
\hline 5 & 2016 & 150.38 & 1.059 & 5128.78 & 145.81 & 1.212 & 5662.64 \\
\hline 6 & 2017 & 159.02 & 1.000 & 4746.80 & 155.34 & 1.101 & 5986.04 \\
\hline 7 & 2018 & 165.36 & 0.900 & 3285.05 & 163.55 & 0.617 & 4683.97 \\
\hline 8 & 2019 & 169.04 & 0.850 & 1716.18 & 168.69 & 0.500 & 1645.68 \\
\hline 9 & 2020 & 170.76 & 0.800 & 758.65 & 170.76 & 0.500 & 536.19 \\
\hline \multicolumn{2}{|c|}{ Amount } & - & - & 33486.46 & - & - & 36275.50 \\
\hline
\end{tabular}

Source: own compilation

\subsection{Option B}

We find the parameters of the regression equation (3) on the basis of the data in Table 1.

The regression equation has the form:

$$
X_{t}=2.4860+0.3608^{* * *} N_{t}-0.002^{* * *} N_{t}^{2}
$$

The characteristics of the regression equation

The characteristics of
$R^{2}=0.834 ; R_{a j s}^{2}=0.801 ; p=0.00012^{* * *}$ 
Note: ***.***_ Significant at 10\%. 5\%. $1 \%$ critical level

Using relations (4), we find the parameters of the Bass model:

$$
p=0.0132 ; q=0.3741 ; m=187.43 \text { mln units }
$$

The Graph 5 shows the distribution of historical data for the period 2003-2016 and the values obtained from the regression model (Bass model).

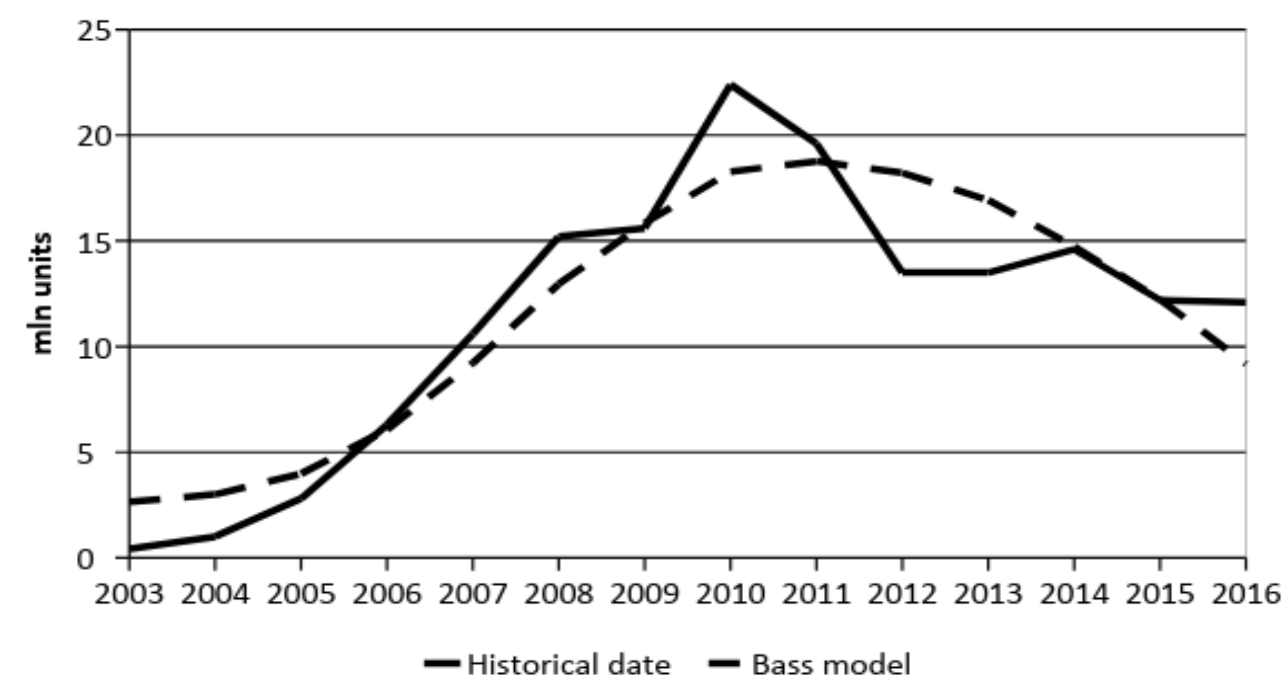

Graph 5. Sony Corporation: unit sales LCD TVs

Source: Investor Relations, Sony, https://www.sony.net/SonyInfo/IR/financial/\#block1

The Graph 6 we represent the distribution of the external influence function on the historical period, found from the relation (7).

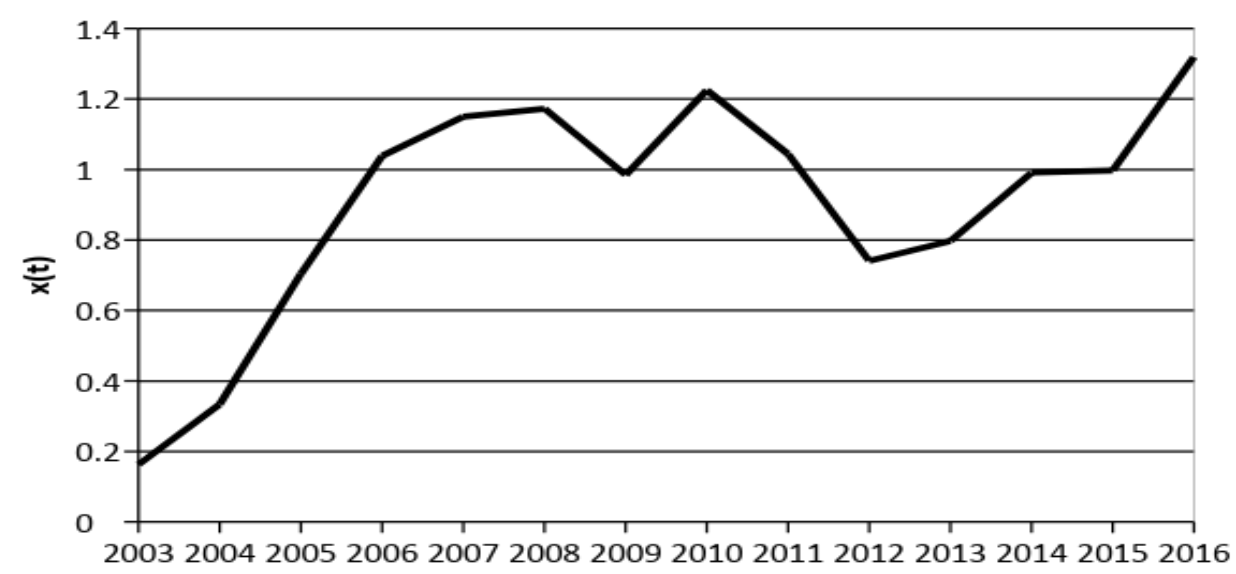

Graph 6. Distribution external function $x(t)$

Source: own data

Let's consider some variants of regression equations. Gross profit (GP) is found from the relation $G P_{t}=n_{t} \operatorname{Pr}_{t}$.

\subsubsection{Option B1}

Based on the studies, we will construct a regression equation on the price parameter $\operatorname{Pr}(t)$ (base 2012) in the interval 2012(t=1) - 2016(t=5).

$$
y(t)=1.468+0.144^{*} t-0.897 \operatorname{Pr}(t)
$$




$$
R^{2}=0.910 ; R_{a d j}^{2}=0.821 ; p=0.089^{*}
$$

Note: *.*****-Significant at 10\%. 5\%. $1 \%$ critical level

In the Graph 7 shows the approximation of the time series $x(t)$ by the regression equation (20).

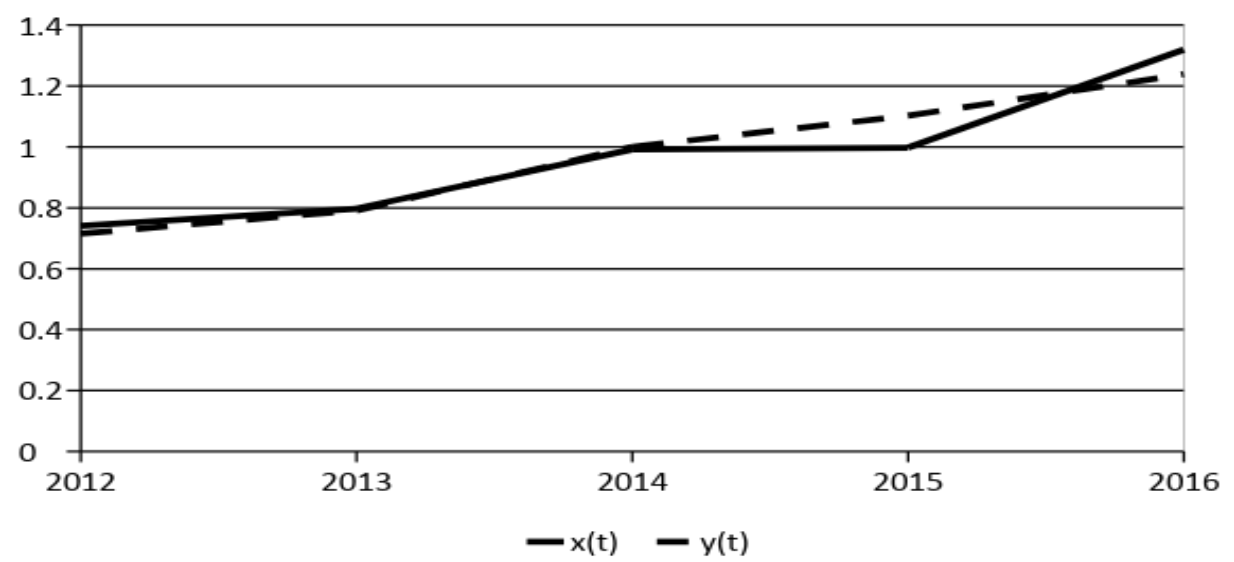

Graph 7. Distribution of external function (Option B1)

Source: own data

We will find the optimal price of the product (Propt), which allows obtaining the maximum balance profit on the interval 2012-2020. The initial and final states of the system are specified by the following conditions: $\mathrm{mln}$ units; mln units. Table 5 shows the corporation's strategy for the period 2012-2020 to conquer the LCD TVs sales market.

Table 5. Sales of LCD TVs (Option B1)

\begin{tabular}{|c|c|c|c|c|c|c|c|}
\hline \multirow[t]{2}{*}{$t$} & \multirow[t]{2}{*}{ Year } & \multicolumn{3}{|c|}{ Calculation based on historical data } & \multicolumn{3}{|c|}{ Optimization results } \\
\hline & & $\begin{array}{l}\text { Total } \\
\text { sales, } \\
\text { mln } \\
\text { units }\end{array}$ & $\begin{array}{c}\text { Unit price, } \\
\text { Pr, (base } \\
2012 \text { ) }\end{array}$ & $\begin{array}{l}\text { Grossprofit } \\
\text { (GP), mln \$ }\end{array}$ & $\begin{array}{l}\text { Total sales, } \\
\text { mln units }\end{array}$ & $\begin{array}{l}\text { Unit price, } \\
\operatorname{Pr}_{\text {opt }}, \\
\text { (base 2012) }\end{array}$ & $\begin{array}{l}\text { Grossprofit } \\
\left(\mathrm{GP}_{\text {opt }}\right), \text { mln \$ }\end{array}$ \\
\hline 1 & 2012 & 107.43 & 1.000 & 6748.40 & 107.43 & 1.142 & 6333.44 \\
\hline 2 & 2013 & 120.71 & 1.075 & 7401.62 & 118.63 & 1.202 & 6979.57 \\
\hline 3 & 2014 & 134.98 & 1.004 & 7424.83 & 130.62 & 1.241 & 7708.38 \\
\hline 4 & 2015 & 149.05 & 1.050 & 7656.16 & 142.94 & 1.246 & 7957.08 \\
\hline 5 & 2016 & 161.14 & 1.059 & 6637.18 & 155.01 & 1.190 & 7445.26 \\
\hline 6 & 2017 & 170.86 & 1.000 & 5035.90 & 166.14 & 1.020 & 5882.05 \\
\hline 7 & 2018 & 177.98 & 0.900 & 3322.73 & 175.56 & 0.607 & 2966.50 \\
\hline 8 & 2019 & 182.54 & 0.850 & 2008.53 & 181.97 & 0.500 & 1659.63 \\
\hline 9 & 2020 & 185.10 & 0.800 & 1062.74 & 185.10 & 0.500 & 812.19 \\
\hline & ount & - & - & 47298.09 & - & - & 47744.09 \\
\hline
\end{tabular}

Source: own compilation

\subsubsection{Option B2}

Using the data in Table 3, we find the regression equation in the interval 2012-2016.

$$
\begin{gathered}
y(t)=-1.188+0.289^{* *} t-1.086 \operatorname{Pr}(t)+2.715^{*} C S(t) \\
R^{2}=0.998 ; R_{a d j}^{2}=0.993 ; p=0.053^{*} .
\end{gathered}
$$


Note:*.**.*** - Significant at 10\%. 5\%. $1 \%$ critical level

In the Graph 8 shows the approximation of the time series $x(t)$ by the regression equation (21).

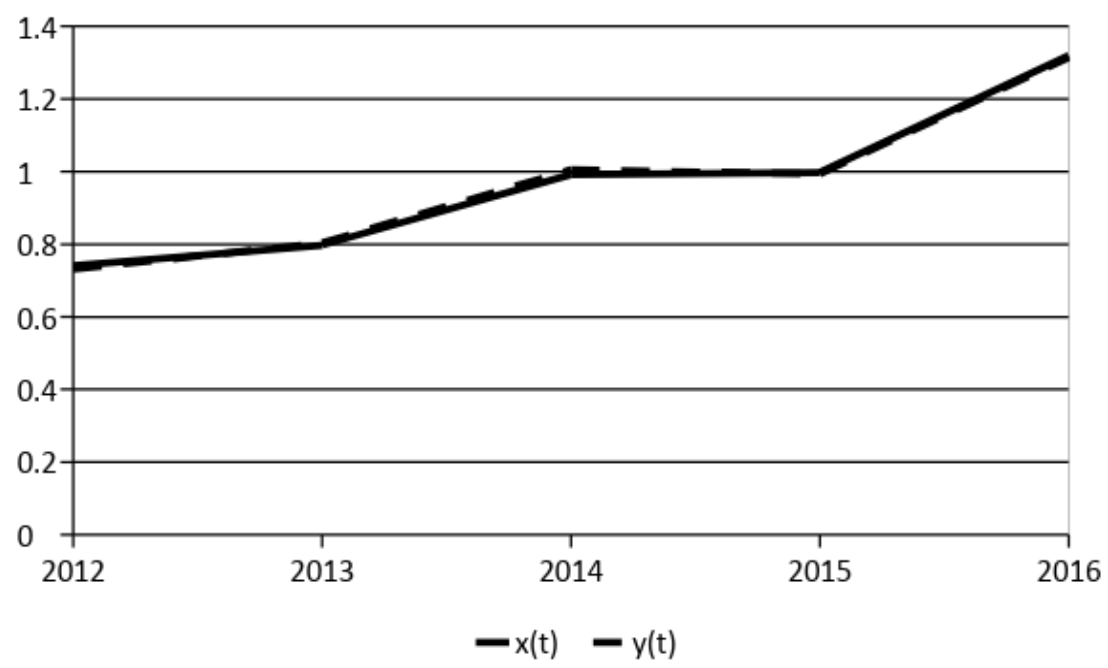

Graph 8. Distribution of external function (Option B2)

Source: own data

We will find the optimal price of the product (Propt), which allows obtaining the maximum balance profit on the interval 2012-2020. The solution of the problem of optimal control of the price function is given in formulae (11) - (13).Table 6 shows the values of the sales characteristics of LCD TVs at a constant value of the indicator of Cost of Sales in the period 2017-2020 at 2016(CS(2016)=43846.95 $\mathrm{mln} \$$ ).

Table 6. Sales of LCD TVs (Option B2)

\begin{tabular}{|c|c|c|c|c|c|c|c|}
\hline \multirow[t]{2}{*}{$t$} & \multirow[t]{2}{*}{ Year } & \multicolumn{3}{|c|}{ Calculation based on historical data } & \multicolumn{3}{|c|}{ Optimization results } \\
\hline & & $\begin{array}{l}\text { Total sales, } \\
\text { mln units }\end{array}$ & $\begin{array}{l}\text { Unit price, } \\
\text { Pr, (base } \\
\text { 2012) }\end{array}$ & $\begin{array}{l}\text { Grossprofit } \\
\text { (GP), mln } \\
\$\end{array}$ & $\begin{array}{l}\text { Total sales, } \\
\text { mln units }\end{array}$ & $\begin{array}{c}\text { Unit price, } \\
\operatorname{Pr}_{\text {opt }}, \\
\text { (base 2012) }\end{array}$ & $\begin{array}{l}\text { Grossprofit } \\
\left(\mathrm{GP}_{\text {opt }}\right) \text {, } \\
\operatorname{mln} \$\end{array}$ \\
\hline 1 & 2012 & 107.43 & 1.000 & 6888.34 & 107.43 & 1.125 & 6309.13 \\
\hline 2 & 2013 & 120.93 & 1.075 & 7524.20 & 118.79 & 1.179 & 6943.79 \\
\hline 3 & 2014 & 135.28 & 1.004 & 7465.42 & 130.88 & 1.201 & 7523.42 \\
\hline 4 & 2015 & 148.65 & 1.050 & 7276.29 & 142.83 & 1.160 & 7187.82 \\
\hline 5 & 2016 & 160.68 & 1.059 & 6604.80 & 154.82 & 1.201 & 7462.41 \\
\hline 6 & 2017 & 171.44 & 1.000 & 5574.94 & 166.63 & 1.097 & 6712.16 \\
\hline 7 & 2018 & 179.32 & 0.900 & 3675.85 & 176.81 & 0.689 & 3635.44 \\
\hline 8 & 2019 & 183.93 & 0.850 & 2032.76 & 183.44 & 0.500 & 1718.20 \\
\hline 9 & 2020 & 186.13 & 0.800 & 909.74 & 186.13 & 0.500 & 697.65 \\
\hline \multicolumn{2}{|c|}{ Amount } & - & 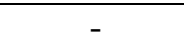 & 47952.35 & 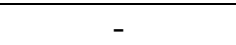 & - & 48190.00 \\
\hline
\end{tabular}

Source: own compilation

\subsection{Algorithm for constructing the Bass model for a changing number of potential adopters}

Let's consider the distribution of an innovative product (LCD TVs) Sony Corporation when changing the amount of the product sold. We assume that the number of potential users increases due to the marketing activities of the corporation. The basis of the new model is the 
results obtained with the help of the Bass theory. At the same time, we will take into account that the innovative component $p$ in the Bass model remains constant, and only the number of potential users and, accordingly, the imitation coefficient $q$ change. For the basis of the new model, let us take the regression equation (18).

The following algorithm for obtaining optimal control over the price of the product is proposed with obtaining the maximum balance profit for the period 2012-2020. At the same time, the total quantity of sold goods varies.

1. Based on the results of historical data, we obtain the regression equation of sales of an innovative product (18).

2. We find the characteristics of the Bass model $p, q_{1}, m_{1}$ (19).

3. Set the required number of potential users of this product $m$.

4. We get a new Bass model with parameters $p, q, m$.

5. We find the external influence function $x(t)$ in the new Bass model, taking into account the deviation of the model from the historical data.

6. We obtain a regression equation describing the change in the external function from external parameters (prices, etc.) (20).

7. We set the expected values of external factors (prices, etc.) in the forecasting interval (2017-2020).

8. We calculate the number of sales and balance profit in the period under review, depending on historical and given forecast values.

9. On the basis of relations (7) - (13) we obtain the optimal value of the product price in the period under study at the maximum balance profit.

10. If necessary, you can calculate the optimal price only for the forecast period (2017-2020).

\subsection{Option C}

We write down the regression equations of the Bass model and the estimates of external influences in a general form:

$$
\begin{aligned}
& X_{t}=a+b N_{t}+c N_{t}^{2} \\
& y_{t}=d_{1}+d_{2} t+d_{3} \operatorname{Pr}_{t}
\end{aligned}
$$

Table 7 shows the parameters of the Bass model $p, q$ and the values presented in formulas (22) and (23), depending on the estimated total amount of the product sold $m$.

Table 7. Parameters for modeling sales of Sony Corporation: LCD TVs

\begin{tabular}{llccccrrrr}
\hline № & $\begin{array}{l}m, \mathrm{mln} \\
\text { units }\end{array}$ & $p$ & $q$ & $a$ & $b$ & $c$ & $d_{1}$ & $d_{2}$ & $d_{3}$ \\
\hline 1 & 187.43 & 0.0132 & 0.3741 & 2.486 & 0.361 & -0.002 & 1.468 & 0.144 & -0.897 \\
\hline 2 & 200.00 & 0.0132 & 0.3991 & 2.330 & 0.386 & -0.002 & 1.338 & 0.069 & -0.762 \\
\hline 3 & 250.00 & 0.0132 & 0.4989 & 1.864 & 0.486 & -0.002 & 0.838 & -0.001 & -0.406 \\
\hline 4 & 300.00 & 0.0132 & 0.5987 & 1.553 & 0.586 & -0.002 & 0.602 & -0.011 & -0.273 \\
\hline
\end{tabular}

Source: own compilation

Table 8 presents the sales characteristics of LCD TVs depending on the needs of the market. The calculations were made for the following criterion: the total number of sales in 2016 is determined on the basis of historical data $\left(N_{2016}=159.83 \mathrm{mln}\right.$ units $)$. 
INTERDISCIPLINARY APPROACH TO ECONOMICS AND SOCIOLOGY

Table 8. Optimal prices and sales of Sony Corporation: LCD TVs

\begin{tabular}{|c|c|c|c|c|c|c|c|c|c|c|}
\hline \multirow[b]{2}{*}{$t$} & \multirow[b]{2}{*}{ Year } & \multicolumn{3}{|c|}{$m=200$, mln units } & \multicolumn{3}{|c|}{$m=250$, mln units } & \multicolumn{3}{|c|}{$m=300$, mln units } \\
\hline & & 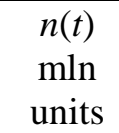 & $\begin{array}{l}N(t) \text { mln } \\
\text { units }\end{array}$ & $\begin{array}{l}\text { Price, } \\
\operatorname{Pr}_{o p t}, \$\end{array}$ & 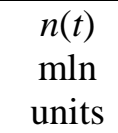 & $\begin{array}{l}N(t) \mathrm{mln} \\
\text { units }\end{array}$ & $\begin{array}{l}\text { Price, } \\
\operatorname{Pr}_{o p t}, \$\end{array}$ & $\begin{array}{l}n(t) \\
\text { mln } \\
\text { units }\end{array}$ & $\begin{array}{l}N(t) \mathrm{mln} \\
\text { units }\end{array}$ & $\begin{array}{l}\text { Price, } \\
\operatorname{Pr}_{\text {opt }}, \$\end{array}$ \\
\hline 1 & 2012 & 12.80 & 107.43 & 543.19 & 13.20 & 107.43 & 548.89 & 13.27 & 107.43 & 543.71 \\
\hline 2 & 2013 & 13.05 & 120.48 & 557.18 & 13.25 & 120.68 & 551.48 & 13.28 & 120.71 & 544.23 \\
\hline 3 & 2014 & 13.33 & 133.81 & 561.33 & 13.24 & 133.92 & 548.37 & 13.24 & 133.95 & 540.08 \\
\hline 4 & 2015 & 13.25 & 147.06 & 549.93 & 13.10 & 147.02 & 540.08 & 13.08 & 147.03 & 531.27 \\
\hline 5 & 2016 & 12.75 & 159.80 & 516.24 & 12.81 & 159.83 & 525.57 & 12.82 & 159.85 & 518.83 \\
\hline 6 & 2017 & 11.77 & 171.57 & 443.67 & 12.39 & 172.22 & 503.80 & 12.48 & 172.33 & 503.28 \\
\hline 7 & 2018 & 10.29 & 181.87 & 302.17 & 11.84 & 184.06 & 474.25 & 12.06 & 184.38 & 484.10 \\
\hline 8 & 2019 & 7.82 & 189.69 & 259.16 & 11.17 & 195.24 & 434.86 & 11.58 & 195.96 & 461.30 \\
\hline 9 & 2020 & 4.72 & 194.41 & 259.16 & 10.39 & 205.62 & 381.99 & 11.05 & 207.02 & 435.90 \\
\hline
\end{tabular}

Source: own compilation

Based on the obtained calculations for all models, it is possible to obtain average values of the propagation parameters of the innovative product in the investigated range.

We assume that the nature of the external impact function obeys the law found in the historical period. Table 9 shows the distribution of the optimal selling price of LCD TVs in the interval 2017-2020 with the following initial data: $N_{2016}=159.83 \mathrm{mln}$ units; $\operatorname{Pr}_{2016}=549.35$ \$.

Table 9. Forecast of future sales of Sony Corporation: LCD TVs

\begin{tabular}{|c|c|c|c|c|c|c|c|c|c|c|}
\hline \multirow[b]{2}{*}{$t$} & \multirow[b]{2}{*}{ Year } & \multicolumn{3}{|c|}{$m=200$, mln units } & \multicolumn{3}{|c|}{$m=250$, mln units } & \multicolumn{3}{|c|}{$m=300$, mln units } \\
\hline & & $\begin{array}{c}n(t), \mathrm{mln} \\
\text { units }\end{array}$ & $\begin{array}{l}N(t) \\
\text { mln } \\
\text { units }\end{array}$ & $\begin{array}{l}\text { Price, } \\
\operatorname{Pr}_{o p t}, \$\end{array}$ & $\begin{array}{c}n(t), \mathrm{mln} \\
\text { units }\end{array}$ & $\begin{array}{l}N(t), \\
\text { mln } \\
\text { units }\end{array}$ & $\begin{array}{l}\text { Price, } \\
\operatorname{Pr}_{\text {opt }}, \$\end{array}$ & $\begin{array}{c}n(t), \mathrm{mln} \\
\text { units }\end{array}$ & $\begin{array}{l}N(t) \\
\text { mln } \\
\text { units }\end{array}$ & $\begin{array}{l}\text { Price, } \\
\operatorname{Pr}_{\text {opt }}, \$\end{array}$ \\
\hline 5 & 2016 & 12.20 & 159.83 & 549.35 & 12.20 & 159.83 & 549.35 & 12.20 & 159.83 & 549.35 \\
\hline 6 & 2017 & 11,19 & 171.02 & 488.25 & 11.85 & 171.68 & 529.71 & 11.74 & 171.57 & 534.38 \\
\hline 7 & 2018 & 9.91 & 180.93 & 369.04 & 11.35 & 183.03 & 503.28 & 11.34 & 182.91 & 516.76 \\
\hline 8 & 2019 & 8.03 & 188.96 & 259.16 & 10.75 & 193.78 & 468.55 & 10.90 & 193.81 & 496.02 \\
\hline 9 & 2020 & 5.05 & 194.01 & 259.16 & 10.05 & 203.83 & 422.42 & 10.42 & 204.22 & 473.22 \\
\hline
\end{tabular}

Source: own compilation

\section{Conclusion}

For a real assessment of the distribution of an innovative product, several forecasting models should be used. One of the main criteria for selecting independent parameters in these models is the ability to control (set) them in the time interval under study. The number of these criteria depends on the historical period and should be limited. The proposed algorithm for obtaining the optimal price of the product, which maximizes the balance profit, allows the calculation of any innovative product. If the product is planned only to be released to the market, then for its further promotion it is necessary to use the analogue indicators or use the standard procedure proposed by Bass. Using the Pontryagin maximum principle, optimal values of sales characteristics (price, quantity of sales) were obtained in the forecast period 2017-2020. A unified approach is proposed for obtaining optimal values when changing 
potential users of this product. The results of the study should be analyzed and choose the most suitable model or stop at the required average characteristics.

The model of forecasting the distribution of an innovative product proposed in this paper is based on the Bass model (1994), and therefore all the limitations that are inherent in this model also apply to the proposed model. When investigating an external function, it is necessary to analyze the behavior of time series. One of the basic requirements for their analysis is to study time radars for stationarity (Dickey and Fuller, 1979). In this connection, further investigation of the proposed model will be correct in the case of stationarity of the obtained time series. When the external influence function is approximated, the regression analysis apparatus is used. Reliable results of the study will be in case when the standard characteristics of the regression equation are significant, and this refers to the analysis of both the entire equation and its variables. The number of independent variables (marketing variables) is limited only by the amount of input data to obtain the regression equation. The forecasted sales of LCD TVs on the basis of the proposed model depend on the pricing policy of the company and therefore the use of this model implies a restriction on the minimum price of this product. The time horizon for forecasting future sales depends on both the market of potential users and the marketing policy of the corporation. Further research involves obtaining dynamic characteristics of innovation coefficients and simulating the Bass model and, on their basis, optimizing future product sales.

\section{References}

Akhmetova, M. (2017). Socio-Economic Environment as the Basis for Innovation Economy. Montenegrin Journal of Economics, 13(2), 175-183.

Ajzen, I. (1991). The theory of planned behavior. Organizational Behavior and Human Decision Processes, 50(2), 179-211. https://doi.org/10.1016/0749-5978(91)90020-T.

Bagozzi, R.P. (2007). The legacy of the technology acceptance model and a proposal for a paradigm shift. Journal of the Association for Information Systems, 8(4), 244-254.

Bass, F. M. (1969). A New Product Growth Model for Consumer Durables. Management Science, 15(5), 215-227, https://doi.org/10.1287/mnsc.15.5.215.

Bass, F. M., Krishnan, T. V., \& Jain, D. C. (1994). Why the Bass Model Fits Without Decision Variables. Marketing Science, 13(3), 203-223, https://doi.org/10.1287/mksc.13.3.203.

Bemmaor, A. (1994). Modeling the Diffusion of New Durable Goods: Word-of-Mouth Effect Versus Consumer Heterogeneity. Research Traditions in Marketing, ed. Gilles Laurent, Gary L. Lilien, and Bernard Pras, 201-229. Boston: Kluwer.

Bemmaor, A., \& Lee.Y. (2002). The Impact of Heterogeneity and Ill-Conditioning on Diffusion Model Parameter Estimates. Marketing Science, 21(2), 209-220, https://doi.org/10.1287/mksc.21.2.209.151.

Benbasat, I., \& Barki, H. (2007). Quo vadis TAM? Journal of the Association for Information Systems, 8(4), 211-218.

Boehner, R., \& Gold, S. (2012). Modeling the Impact of Marketing Mix on the Diffusion of Innovation in the Generalized Bass Model of Firm Demand. Developments in Business Simulation and Experiential Learning, 39, 75-91.

Boswijk, H. P., \& Franses, P. H. (2005). On the econometrics of the Bass diffusion model. Journal of Business \& Economic Statistics, 23(3), 255-268, http://dx.doi.org/10.1198/073500104000000604.

Cieślik, A., \& Michałek, J. (2017). Innovation Forms and Firm Export Performance: Empirical Evidence from ECA Countries. Entrepreneurial Business and Economics Review, 5(2), 85-99. doi: https://doi.org/10.15678/EBER.2017.050205 
Chandrasekaran, D., \& Tellis, G. J. (2007). A Critical Review of Marketing Research on Diffusion of New Products. In Naresh K. Malhotra, Review of Marketing Research, 3, Armonk: M.E. Sharpe, 39-80.

Chatterjee, R., \& Eliashberg, J. (1990). The Innovation Diffusion Process in a Heterogeneous Population: A Micro Modeling Approach. Management Science, 36(4), 1057-1079. https://doi.org/10.1287/mnsc.36.9.1057.

Chen, L., Gillenson, M., \& Sherrrell, D. (2002). Enticing online consumers: An extended technology acceptance perspective. Information and Management, 39(8), 705-719, https://doi.org/10.1016/S0378-7206(01)00127-6.

Davis, F. D. (1989). Perceived usefulness, perceived ease of use, and user acceptance of information technology. MIS Quarterly, 13(3), 319-340, https://doi.org/10.2307/249008.

Davis, F.D., Bagozzi, R.P., \& Warshaw, P.R. (1989).User acceptance of computer technology: A comparison of two theoretical models. Management Science, 35(8), 982-1003, https://doi.org/10.1287/mnsc.35.8.982 .

Deleersnyder, B., Dekimpe, M., Sarvary, M., \& Parker, P. (2004).Weathering Tight Economic Cycles: The Sales Evolution of Consumer Durables over the Business Cycle. Quantitative Marketing and Economics, 2(4), 347-383. https://doi.org/10.1007/s11129-004-0137-x.

Dickey, D. A., \& Fuller, W. A. (1979). Distribution of the Estimators for Autoregressive Time Series With a Unit Root. Journal of th eAmerican Statistical Association, 74(366), 427-431, http://dx.doi.org/10.1080/01621459.1979.10482531.

Easingwood, C.J., Mahajan, V., \& Muher, E. (1983). A non-uniform influence innovation diffusion model of new product acceptance. Marketing Science, 2(3), 273-295. https://doi.org/10.1287/mksc.2.3.273.

Franses, P.H. (2009). Forecasting Sales. Econometric Institute. Erasmus University. Rotterdam. Econometric Institute, Report 2009-29.

Fruchter, G. E., \& Vanden Bulte, C. (2011). Why the Generalized Bass Model leads to odd optimal advertising policies.International Journal of Researchin Marketing, 28(3), 218-230. https://doi.org/10.1016/j.ijresmar.2011.03.005.

Garber, T., Goldenberg, J., Libai, B., \& Muller, E. (2004). From Density to Destiny: Using Spatial Dimension of Sales Data for Early Prediction of New Product Success. Marketing Science, 23(3), 419-428, https://doi.org/10.1287/mksc.1040.0051.

Gerpott, T. J. (2005). Strategisches Technologie- und Innovationsmanagement, 2. Aufl., Stuttgart.

Golder, P. N., \& Tellis, G. J. (1998). Beyond Diffusion: An Affordability Model of the Growth of New Consumer Durables, Journal of Forecasting, 17(3/4), 259-280.

Golder, P. N., \& Tellis, G. J. (2004). Growing, Growing, Gone: Cascades, Diffusion, and Turning Points of the Product Life Cycle. Marketing Science, 23(2), 207-218. https://doi.org/10.1287/mksc.1040.0057.

Granger, C. W. J. (1969).Investigating Causal Relations by Econometric Models and Crossspectral Methods. Econometrica, 37(3), 424-438, https://doi.org/10.2307/1912791.

Ha, C. L. (1998). The theory of reasoned action applied to brand loyalty. Journal of Product \& Brand Management, 7(1), 51-61: https://doi.org/10.1108/10610429810209737.

Horsky, D. (1990). A Diffusion Model Incorporating Product Benefits, Price, Income and Information. Marketing Science, 9, 342-365. https://doi.org/10.1287/mksc.9.4.342.

Irvine, J., \& Martin, B. R. (1984). Foresight in Science - Picking the Winners, London.

Ivanová, E., \& Čepel, M. (2018). The Impact of Innovation Performance on the Competitiveness of the Visegrad 4 Conutries. Journal of Competitiveness, 10(1), 5472 . 
Kiwanuka, A. (2015). Acceptance Process: The Missing Link between UTAUT and Diffusion of Innovation Theory. American Journal of Information Systems, 3(2), 40-44.

Kotsemir, M., \& Meissner, D. (2013). Conceptualizing the innovation process-trends and outlook. Basic research program, Working papers, Series: science, technology and innovation. WP BPR 10/STI/2013. http://dx.doi.org/10.2139/ssrn.2249782.

Kozlovskyi, S. et al. (2018). Modeling and Forecasting the Level of State Stimulation of Agricultural Production in Ukraine Based on the Theory of Fuzzy Logic. Montenegrin Journal of Economics, 14(3), 037-053.

Lee, Y.H., Hsieh, Y.C., and Hsu, C.N. (2011). Adding Innovation Diffusion Theory to the Technology Acceptance Model: Supporting Employees' Intentions to use E-Learning Systems.Educational Technology \& Society, 14(4), 124-137.

Lowry, P. B., Gaskin, J.,Twyman, N. W., Hammer, B., \& Roberts, T. L. (2013). Taking fun and games seriously: Proposing the hedonic-motivation system adoption model (HMSAM). Journal of the Association for Information Systems (JAIS), 14 (11), 617671.

Marinova, D., \& Phillimore J. (2003). Models of innovation. In Shavinina L.V. (Ed.).The International Handbook on Innovation. Oxford. Elsevier, 44-53.

Olefirenko, O. (2016). Methodic tools to optimize marketing expenses of the innovatively active industrial enterprises in Ukraine. Problems and Perspectives in Management, 14(1). https://doi.org/10.21511/ppm.14(1).2016.05.

Oren, S., \& Schwartz, R. (1988). Diffusion of New Products in Risk-Sensitive Markets. Journal of Forecasting, 7(4), 231-287. https://doi.org/10.1002/for.3980070407.

Pandey, S., \& Srivastava, S. (2016). Antecedents of Customer Purchase Intention. Journal of Business and Management, 18(10), 55-82. https://doi.org/10.9790/487X-1810035582.

Pontryagin, L.S, Boltyanskii, V.G, Gamkrelidze, R.V., \& Mishchenko, E.F. (1962). The mathematical theory of optimal processes. New York-London. Intersciene Publishers John Wiley\&Sons, Inc.

Redmond, W. (1994). Diffusion at Sub-National Levels: A Regional Analysis of New Product Growth. Journal of Product Innovation Management, 11(3), 201-212. https://doi.org/10.1111/1540-5885.1130201.

Reichardt, T. (2008). Bedürfnisorientierte Marktstrukturanalyse für technische Innovationen: Eine empirische Untersuchung am Beispiel Mobile Commerce, Wiesbaden.

Robertson, T. S. (1967). The Process of Innovation and the Diffusion of Innovation. Journal of Marketing, 31(1), 14-19. https://doi.org/10.2307/1249295.

Rogers, E. M. (1961). Characteristics of agricultural innovators and other adopter categories, Ohio Agricultural Experiment Station, Research bulletin 882, Wooster.

Rogers, E. M. (1969). Communication Research and Rural Development. Canadian Journal of African Studies, 3(1), 216-222/ http://dx.doi.org/10.1080/00083968.1969.10803540.

Rogers, E. M. (2003). Diffusion of Innovation. 5. Aufl., New York.

Song, I., \& Chintagunta, P. (2003). A Micromodel Of New Product Adoption with Heterogeneous and Forward Looking Consumers: Application to the Digital Camera Category. Quantitative Marketing and Economics, 1(4), 371-407. https://doi.org/10.1023/B:QMEC.0000004843.41279.f3.

Srinivasan, S., \& Mason, C. H. (1986). Nonlinear least squares estimation of new product diffusion models. Marketing Science, 5(2), 169-178. https://doi.org/10.1287/mksc.5.2.169.

Steffens, P.R., \& Murthy, D.N.P. (1992). A Mathematical Model for New Product Diffusion: The Influence of Innovators and Imitators. Mathematical and Computer Modelling, 16(4), 11-26, https://doi.org/10.1016/0895-7177(92)90031-F. 
Sultan, F., Farley, J.U., \& Lehmann, D.R. (1990). A Meta-Analysis of Applications of Diffusion Models. Journal of Marketing Research, 27(1), 70-77, https://doi.org/10.2307/3172552.

Talukdar, D., Sudhir, K., \& Ainslie, A. (2002). Investigating New Product Diffusion Across Products and Countries. Marketing Science, 21(1), 97-114. https://doi.org/10.1287/mksc.21.1.97.161.

Tanny, S. M., \& Derzko, N. A. (1988). Innovators and imitators in innovation diffusion modelling, Journal of Forecasting, 7(4), 225-234, https://doi.org/10.1002/for.3980070403.

Taylor, S., \& Todd, P.A. (1995). Understanding Information Technology Usage: A Test of Competing Models. Information Systems Research, 6(2), 144-176. https://doi.org/10.1287/isre.6.2.144.

Urban, G. L., Weinberg, B. D., \& Hauser, J. R. (1996). Premarket Forecasting of Really-New Products. Journal of Marketing, 60(1), 47-60. https://doi.org/10.2307/1251887.

Van Den Bulte, C., \& Stremersch, S. (2004). Social Contagion and Income Heterogeneity in New Product Diffusion: A Meta-Analytic Test. Marketing Science, 23(4), 530-544, https://doi.org/10.1287/mksc.1040.0054.

Venkatesh, V., Morris, M.G., Davis, G.B., \& Davis, F.D. (2003). User acceptance of information technology: Toward a unified view. MIS Quarterly, 27(3), 425-478.

Wach, K. (2016). Innovative Behaviour of High-Tech Internationalized Firms: Survey Results from Poland. Entrepreneurial Business and Economics Review, 4(3), 153-165. doi: https://doi.org/10.15678/EBER.2016.040311

Yurynets, Z., Yurynets, R., \& Gutor, T. (2017).Game theory model for the development of optimal strategy towards innovative products manufacturing at the enterprise. Problems and Perspectives in Management, 15(3), 285-294, https://doi.org/10.21511/ppm.15(31).2017.12.

Investor Relations, Sony. Retrieved from: https://www.sony.net/SonyInfo/IR/financial/\#block1. 